\title{
Present Status of Rooftop Gardening in Sylhet City Corporation of Bangladesh: an Assessment Based on Ecological and Economic Perspectives
}

\author{
Md. Habibur Rahman ${ }^{1,3, \star}$, Mizanur Rahman ${ }^{1,2}$, Md. Mostafa Kamal ${ }^{1}$, Md. Jasim Uddin ${ }^{1}$, Most. Jannatul Fardusi ${ }^{1,3}$ \\ and Bishwajit Roy ${ }^{1,3}$ \\ ${ }^{1}$ Department of Forestry and Environmental Science, School of Agriculture and Mineral Sciences, Shahjalal University of Science and Technology, \\ Sylhet 3114, Bangladesh \\ ${ }^{2}$ Department of Forest and Nature Conservation, Wageningen University, Lalmatia, The Netherlands \\ ${ }^{3}$ Bangladesh Institute of Social Research (BISR), Dhaka 1207, Bangladesh
}

\begin{abstract}
Present study analyzes the rooftop gardening status, floristic composition and cost and return of the rooftop garden in Sylhet City Corporation of northeastern Bangladesh. Data was collected from 450 rooftop gardeners randomly during July-September 2010. Study reveal that rooftop gardening is generally for mental satisfaction (95.3\%) followed by leisure time activity (87.8\%) in the study area and almost all the family members of gardeners' were involved; while collection of planting materials, sites preparation and marketing of products were reported to be carried out by males only (male 71.33\%). Middle income classes were most interested in rooftop gardening (43.78\%). The survey recorded 53 plant species (35 families) of which Cucurbitaceae family represented highest eight species. Shrubs (28\%) were highest followed by herbs (26\%) among agri-crops (36\%) and flower species (30\%). About $89 \%$ of the rooftop gardeners procured planting materials from nursery, market, fair, neighbor, relative and friends and they mostly prefer to use seedlings (48\%) for roof gardening followed by direct seed sowing (21\%). Gardeners sell products sporadically in different local markets, directly or through intermediaries, with no uniform pricing for system. Rooftop gardening improves the food security and meet nutritional deficiency to the gardeners. Survey revealed that generally very few people consider rooftop gardening commercially to get profit and from the cost-return analysis this gardening system can be economically viable if proper and scientifically managed. The study conclude that active government and NGOs could play vital role to increasing this activities by providing training and motivate people with technical aspects of rooftop gardening.
\end{abstract}

Key Words: leisure time activity, planting materials, growing medium, food security, marketing channel, sylhet

\section{Introduction}

Rooftop gardens, as a specific urban gardening niche set within a broader system of city gardens, enjoy their own set of distinctive benefits. Roof top gardening is generally defined as an art and science of growing plants on the fallow spaces within, surrounding or adjacent to the residence, most frequently referred to as a garden. Other conservative areas of roof gardening include atrium, balcony and window boxes. Plants are grown for a variety of utilitarian and non-utilitarian purposes (Sajjaduzzaman et al. 2005). Rooftop garden can supplement the diets of the community

Received: November 11, 2011. Revised: March 2, 2012. Accepted: March 14, 2012. 
it feeds with fresh produce and provide a tangible benefits tie to food production. Also contributes to food security by increasing the supply of food and by enhancing the quality of perishable foods reaching urban consumers (Koc et al. 1999; Mann 2001; Bellows and Hamm 2003; Hamm and Bellows 2003).

Urban plantings additionally improve urban air quality by trapping and absorbing nitrous oxides, volatile organic compounds, and airborne particulate matter (Sedjo 1989; Pant 1994). Rooftop gardens overcome the problem of restrictive land costs and the pressure that many urban gardens face from competing land uses like housing developments (Nowak 2004). In Switzerland and parts of Germany, this kind of mental shift-resulting in imagining buildings as displacing and not destroying land surface-has become federal law: developers must either improve the biodiversity of existing land, or transfer the green space that they displace to their rooftop or other building surface (GRIS 2004). Even old buildings are required to transfer one-fourth of the land they have displaced to their roofs (Peck 2003).

Sylhet, the north-eastern administrative division of Bangladesh, has a number of topographical features like hills and hillocks, haors (wetland), forests lands and high flood plain; which made it quiet different from the rest of the parts of Bangladesh. But the city has been developed in an unplanned and haphazard way. Serious problems of environmental degradation in Sylhet city stemming from urbanization may be evaluated in the form of land use alterations, inadequate solid waste management, traffic congestion, water logging, drainage congestion, inadequate public water supply, lack of proper sanitation, air pollution, noise pollution, hill cutting, lowering of groundwater level, etc. (Rahman 2010). Yet almost without exception, people have the desire to be near green foliage (Bienz 1980). The planners have recognized the values and importance of greening its immediate surroundings for aesthetic, economic and protection purposes (Brown et al. 2004).

Therefore, rooftop gardens support the social life, as a space to be comfortable outdoor environment with family and friends. It also develops a sense of self identity and independence, where one can primarily achieve self and emotion regulation viewing different flower indifferent seasons (Rashid and Ahmed 2009) and affords restorative experi- ence from demanding everyday activities in urban high rise residential building. Thus study has been conducted to (i) present status and floristic composition of rooftop gardening along with its management aspects, and (ii) make an economic analysis (cost and return) of rooftop gardening in Sylhet City Corporation of Bangladesh.

\section{Study Area}

The study was conducted in Sylhet City Corporation (SCC) area of Sylhet district, geographically SCC lies between $24^{\circ} 32^{\prime} 0^{\prime \prime} \mathrm{N}$ and $91^{\circ} 52^{\prime} 0^{\prime \prime} \mathrm{E}$ on the northern bank of the Surma River. SCC has an area of about 26.5 square kilometers consists of 27 wards with an estimated population of more than 500,000 and population density is 17,479 per km² (BBS 2009; SCC 2010). The total number of households in the city is approximately 55,514. SCC experiences a hot, wet and humid tropical climate. The city is within the monsoon climate zone, with annual average highest temperatures of $31.8^{\circ} \mathrm{C}$ (March-May) and average lowest temperature of $12.9^{\circ} \mathrm{C}$ (November to February). Nearly $80 \%$ of the annual average rainfall of $3,334 \mathrm{~mm}$ occurs between May and September (BBS 2009; Rahman et al. 2012).

\section{Research Method}

This present empirical study was done during July-September 2010. For the study we first divided the area into three zones such as residential area; market area and institutional area on the basis of their densities thus cover the whole city area. From the residential zone we selected the four areas (Housing Estate, Amberkhana, Modina Market and Tilaghor); from the market zone two areas (Uposohor and Bondor Bazar); from the institutional zone selected three areas (Sobid Bazar, Zindabazar and Jalalabad) for the study. A total of 450 rooftop gardens were selected randomly from the selected three zones (residential zone 200, market zone 100, and institutional zone 150) for the survey (Table 1). A semi-structured questionnaire was developed for interviewing rooftop gardeners through direct observation. Respondents were free to express their own view at each step of the interview. Interviews were performed during daytime, with an average duration of about 
Table 1. Summary of survey on roof gardening in Sylhet City Corporation area, Bangladesh

\begin{tabular}{lrcc}
\hline \multirow{2}{*}{ Name of the area } & $\begin{array}{c}\text { House surveyed } \\
\text { (No.) }\end{array}$ & \multicolumn{2}{c}{ Garden placed (\%) } \\
\cline { 3 - 4 } & 200 & 61.5 & 38.5 \\
\hline Residential zone & 50 & 34 & 66 \\
Housing estate & 50 & 62 & 38 \\
Amberkhana & 50 & 72 & 28 \\
Modina market & 50 & 78 & 22 \\
Tilaghor & 100 & 63 & 37 \\
Market zone & 50 & 74 & 26 \\
Uposohor & 50 & 52 & 48 \\
Bondor bazar & 150 & 58.7 & 41.3 \\
Institutional zone & 50 & 40 & 60 \\
Sobid bazar & 50 & 70 & 30 \\
Zindabazar & 50 & 66 & 34 \\
Jalalabad & & & \\
\hline
\end{tabular}

50 minutes. Data were sought on rooftop gardening like size, species composition, purposes, sources and cost of planting materials, labor input, cultivation process, production, selling price, marketing channels and problems related to rooftop gardening in the study area. Demographic and socio-economic data were also collected from the gardeners. All qualitative and quantitative data were collected in local terms and units. On each survey topic, respondents were encouraged to express their views and provide additional information regarding rooftop gardening in the area. Cost and return of rooftop gardening were collected to exploring out the economic analysis. Approximate annual return of the local rooftop gardeners were estimated through careful questioning of gardeners where the values of total inputs e.g. fixed cost, variable cost (planting and maintenance, transportation, etc.) and returns e.g. fruits, flowers, vegetables, etc. sales were estimated at the current price (Tk.) [Tk. means Taka, Bangladeshi currency. 1 $\mathrm{US} \$=$ Tk. 73 as of 15 October, 2011].

\section{Results and Discussion}

\section{Basic socio-economic and demographic features of the gardeners}

Urban growth resulted in tremendous increase of population and infrastructure. Current environmental, social and economic realities have inspired a new generation of city dwellers to find innovative ways to live more sustainable. Rooftop gardening is the only solution in this situation to meet the daily needs of city dwellers such as vegetables, fruits and flowers. Like other nursery or garden sectors in Bangladesh the number of male gardeners was more in our study area, but the percentage of female gardeners $(40.67 \%)$ were impressive. Women have greater opportunity to come forward in this scheme with their household work as they don't need extra time and care for this. The only major problem of women was to ensure marketing facilities directly considering the social taboos of study area. Rooftop gardeners have come from a wide range of ages. Age class $31-40$ years $(41.56 \%)$ and $41-50$ years (30.22\%) occupies the mentionable percentage of gardener. These two groups are generally involved in gardening using their part time or as a side business, which add for their extra income. But all gardeners from different age-classes are consent about the reason behind why they have been interested in rooftop gardening and the reason is that rooftop garden requires less investment, less labor, less time, less land and less cultural activities but having high profit such as beautification and mental satisfaction. Years of schooling of the gardeners found to be higher in $>10-12$ years $(39.78 \%)$. The major income activities of rooftop gardeners were centered on government job (25.56\%), while involvement in rooftop gardening by the retired employee was $17.33 \%$.

Lower income classes (18.67\%) were less interested in roof gardening activities because they lack of own residence and even if they possess, most of them were not possess building i.e. not suitable for roof gardening. Middle income classes were most interested in rooftop gardening $(43.78 \%)$. Almost all the family members of gardeners' were involved in gardening. Collection of planting materials, selection of species and preparation of sites, maintenance and sale of products were reported to be carried out by males only, while other cultural operations were performed collectively by males, females and children. The basic socio-economic and demographic feature of the rooftop gardeners in SCC area is shown in Table 2.

\section{Status and species composition of rooftop garden- ing in SCC}

$\mathrm{SCC}$ is the latest modern city in Bangladesh with having 
Table 2. Basic socio-economic and demographic features of rooftop gardeners in Sylhet City Corporation area, Bangladesh

\begin{tabular}{|c|c|c|c|}
\hline Variable name & Frequency & Percent & $\begin{array}{l}\text { Cumulative } \\
\text { percent }\end{array}$ \\
\hline \multicolumn{4}{|l|}{ Religion } \\
\hline Muslim & 318 & 70.67 & 70.67 \\
\hline Hindu & 87 & 19.33 & 90 \\
\hline Buddhist & 17 & 3.78 & 93.78 \\
\hline Christian & 28 & 6.222 & 100 \\
\hline \multicolumn{4}{|l|}{ Gender } \\
\hline Male & 267 & 59.33 & 71.33 \\
\hline Female & 183 & 40.67 & 100 \\
\hline \multicolumn{4}{|l|}{ Age class (years) } \\
\hline $21-30$ & 46 & 10.22 & 10.22 \\
\hline $31-40$ & 187 & 41.56 & 51.78 \\
\hline $41-50$ & 136 & 30.22 & 82 \\
\hline$>50$ & 81 & 18 & 100 \\
\hline \multicolumn{4}{|c|}{$\begin{array}{l}\text { Education (years of schooling of } \\
\text { the gardeners) }\end{array}$} \\
\hline $5-10$ & 95 & 21.11 & 21.11 \\
\hline$>10-12$ & 179 & 39.78 & 60.89 \\
\hline$>12-15$ & 133 & 29.56 & 90.44 \\
\hline$>15$ & 43 & 9.556 & 100 \\
\hline \multicolumn{4}{|l|}{ Occupation } \\
\hline Government job & 115 & 25.56 & 25.56 \\
\hline NGOs job & 77 & 17.11 & 42.67 \\
\hline Business & 136 & 30.22 & 72.89 \\
\hline Unemployed & 44 & 9.78 & 82.67 \\
\hline Retired employee & 78 & 17.33 & 100 \\
\hline \multicolumn{4}{|c|}{ Income category (Tk.) per year } \\
\hline $\begin{array}{l}\text { Lower income class } \\
(132,000-170,000)\end{array}$ & 84 & 18.67 & 18.67 \\
\hline $\begin{array}{l}\text { Middle income class } \\
(171,000-300,000)\end{array}$ & 197 & 43.78 & 62.44 \\
\hline $\begin{array}{l}\text { Higher income class } \\
(>300,000)\end{array}$ & 169 & 37.56 & 100 \\
\hline
\end{tabular}

tall buildings that are generally used for residential purposes, institutions, markets, shopping centers, hotels, restaurants and various important offices including public and private organizations. The survey shows that out of 450 rooftop gardens, on an average $61.5 \%$ of the houses were bestowed with gardens in roofs and $38.5 \%$ in balconies in the residential zone, in the market zone $63 \%$ and $37 \%$ possess gardens in either roof and in balcony and in the institutional zone $58.7 \%$ possess in roof and $41.3 \%$ in balcony (Table 1).

The survey recorded 53 plant species, belonging to 35 families generally raised in the rooftop gardens (Table 3), which were categorized into agri-crops (36\%), flower species $(30 \%)$, fruit species (21\%) and medicinal plants (13\%). Although 35 families were recorded, Cucurbitaceae represented highest eight species, followed by Solanaceae and Amaranthaceae were represented by four and three species respectively; 6 families had two species each and the other 26 had just one species each. These plants include shrubs (28\%), herbs (26\%), trees (23\%), climbers $(21 \%)$ and cactus $(2 \%)$. Survey data revealed that gardeners preferred those species which needs small space for growing and needs low maintenance cost and time. Moreover, agri-crops species preferred more as these species meet the daily vegetables needs of the gardeners and flowering plants increasing the visual beauty of the house. Tree species were planted mainly for fruits and medicinal purposes. Results also found that same agri-crops and flowering plants are generally more or less common in all gardens. The green plants and flora in the house influence the feeling of harmony, simplicity and authenticity. Natural green has significant effect on overall life satisfaction and improve the occupant's wellbeing (Rashid et al. 2010). So, species selection for roof gardening is an important task for every gardeners.

\section{Sources and growing medium of planting materials}

Roof gardening is not an easy going activities like conventional gardening as it's success largely depend on suitable species selection, appropriate containers, proper cultural methods and sufficient supervision and control. The survey reveals that $89 \%$ roof gardeners use planting materials procured from abroad (nursery, market, fair, neighbor, relative and friends). A few percent (11\%) of planting materials was produced by the gardeners using seed, rhizome, root and stem, etc. The users aware that the species should be of bushy, shade tolerant, ornamental and high yielding nature. It is found that for rooftop gardening in the study area, $77 \%$ earthen containers, $8 \%$ cemented bed, $7 \%$ drums, $5 \%$ brass made pots and $3 \%$ others are in use. Bienz (1980), opined that suitable growing medium must be prepared ensuring sufficient water and mineral elements. It is found from the study that the gardeners mostly prefer to use the seedlings (48\%) for roof gardening followed by direct seed sowing $(21 \%)$, propagated materials (16\%), stem cutting (11) and from root (4\%). 
Management system of rooftop gardening is same as conventional gardening. From the survey it was found that gardeners generally followed various management approaches such as watering in two times (in the morning and afternoon), applying both organic and inorganic fertilizers such as green manure (compost), cow dung and a mixture of urea, phosphorous and triple super phosphate [TSP]) and insecticides when necessary. Weeding was done gen- erally in the seedling stage of the plant and subsequent weeding was done when it necessary although sometimes replanting was carried out when plant was died. Change of soil in rooftop gardening is not a common phenomenon but when soil is affected by the insects than it also done.

\section{Purpose of rooftop gardening}

Green rooftop and green verandah for urban residents is

Table 3. Species composition, preference and occurrence of different rooftop gardens in Sylhet City Corporation of Bangladesh

\begin{tabular}{|c|c|c|c|c|c|c|}
\hline & Local name & Scientific name & Family & Habit & Preference & Occurrence \\
\hline \multirow[t]{19}{*}{ Agri-crops } & Ada & Zingiber otficinale Roscoe & Zingiberaceae & $\mathrm{H}$ & + & $\mathrm{FC}$ \\
\hline & Alo & Solanum tuberosum Linn. & Solanaceae & $\mathrm{Cl}$ & + & $\mathrm{R}$ \\
\hline & Anaros & Ananus cosmos (Linn.) Merr. & Bromiliaceae & $\mathrm{H}$ & + & $\mathrm{R}$ \\
\hline & Begun & Solanum melongena Wall. & Solanaceae & Sh & ++ & $\mathrm{C}$ \\
\hline & Cal kumra & Benincasa hispida (Thunb.) Cogn. in DC. & Cucurbitaceae & $\mathrm{Cl}$ & +++ & $\mathrm{C}$ \\
\hline & Data shak & Amanarthus lividus Roxb. & Amaranthaceae & $\mathrm{H}$ & + & $\mathrm{FC}$ \\
\hline & Dhondul & Luffa cylindrica (Linn.) M.Roem & Cucurbitaceae & $\mathrm{Cl}$ & ++ & $\mathrm{R}$ \\
\hline & Dhonia & Coriandrum sativum Linn. & Umbelliferae & $\mathrm{H}$ & + & $\mathrm{FC}$ \\
\hline & Jinge & Luffa acutangula (L.) Roxb. & Cucurbitaceae & $\mathrm{Cl}$ & ++ & $\mathrm{FC}$ \\
\hline & Kakrol & Momordica cochinchinensis (Lour.) Spreng. & Cucurbitaceae & $\mathrm{Cl}$ & + & $\mathrm{R}$ \\
\hline & Korolla & Momordica charantia Linn. var. & Cucurbitaceae & $\mathrm{Cl}$ & ++ & $\mathrm{FC}$ \\
\hline & Lal shak & Amaranthus tricolor Linn. & Amaranthaceae & $\mathrm{H}$ & ++ & $\mathrm{FC}$ \\
\hline & Lao & Lagenaria siceraria (Molina) Standl. & Cucurbitaceae & $\mathrm{Cl}$ & ++ & $\mathrm{FC}$ \\
\hline & Misti kumra & Cucurbita maxima Duch. ex Lmk. & Cucurbitaceae & $\mathrm{Cl}$ & +++ & $\mathrm{FC}$ \\
\hline & Morich & Capsicum frutescens Linn. & Solanaceae & $\mathrm{Sh}$ & +++ & $\mathrm{C}$ \\
\hline & Poi shak & Basella rubra Linn. & Begoniaceae & $\mathrm{Cl}$ & +++ & $\mathrm{C}$ \\
\hline & Sim & Lablab purpureus (Linn.) Sweet & Fabaceae & $\mathrm{Cl}$ & +++ & $\mathrm{C}$ \\
\hline & Sosa & Cucumis sativus Linn. & Cucurbitaceae & $\mathrm{Cl}$ & + & $\mathrm{R}$ \\
\hline & Tomato & Lycopersicon esculentum Mill. & Solanaceae & $\mathrm{Sh}$ & ++ & $\mathrm{FC}$ \\
\hline \multirow{7}{*}{$\begin{array}{l}\text { Medicinal } \\
\text { plants }\end{array}$} & Arohor & Cajanus cajana (Linn.) Huth. & Leguminosae & $\mathrm{Sh}$ & + & $\mathrm{R}$ \\
\hline & Bashok & Adhatoda vasica Nees & Acanthaceae & Sh & + & $\mathrm{FC}$ \\
\hline & Mehendi & Lawsonia inermis Linn. & Lythraceae & $\mathrm{Sh}$ & +++ & $\mathrm{FC}$ \\
\hline & Neem & Azadiracta indica A. Juss. & Meliaceae & $\operatorname{Tr}$ & ++ & $\mathrm{R}$ \\
\hline & Pathor kuchi & Kalanchoe pinnata (Lam)Pers & Crassulaceae & $\mathrm{H}$ & ++ & $\mathrm{FC}$ \\
\hline & Thankuni & Centella asiatica (Linn.) Urban & Umbelliferae & $\mathrm{H}$ & ++ & $\mathrm{FC}$ \\
\hline & Tulsi & Ocimum sanctum Linn. & Labiatae & $\mathrm{H}$ & +++ & $\mathrm{C}$ \\
\hline \multirow[t]{11}{*}{ Fruit species } & Aam & Mangifera indica Linn. & Anacardiaceae & $\operatorname{Tr}$ & +++ & $\mathrm{C}$ \\
\hline & Aorbori & Phyllanthus acidus (L.) Skiels & Euphorbiaceae & $\operatorname{Tr}$ & ++ & $\mathrm{FC}$ \\
\hline & Boroi & Zizyphus mauritiana Lamk. & Rhamnaceae & $\operatorname{Tr}$ & ++ & $\mathrm{C}$ \\
\hline & Dalim & Punica granatum Linn. & Punicaceae & $\operatorname{Tr}$ & ++ & $\mathrm{FC}$ \\
\hline & Golap jam & Syzygum jambos (Linn.) Alston & Myrtaceae & $\operatorname{Tr}$ & + & $\mathrm{R}$ \\
\hline & Guava & Psidium guajava (Linn.) Bat. & Myrtaceae & $\operatorname{Tr}$ & +++ & $\mathrm{C}$ \\
\hline & Jambura & Citrus grandis (Linn.) Osbeck. & Rutiaceae & $\operatorname{Tr}$ & ++ & $\mathrm{FC}$ \\
\hline & Kamranga & Averrhoa carambola Linn. & Averrhoaceae & $\operatorname{Tr}$ & +++ & $\mathrm{C}$ \\
\hline & Lebu & Citrus limon (Linn.) Burm.f. & Rutiaceae & $\operatorname{Tr}$ & +++ & $\mathrm{C}$ \\
\hline & Litchi & Litchi chinensis Sonner & Sapindaceae & $\operatorname{Tr}$ & + & $\mathrm{R}$ \\
\hline & Papaya & Carica papaya Linn. & Caricaceae & $\mathrm{Sh}$ & +++ & $\mathrm{C}$ \\
\hline
\end{tabular}


Table 3. Continued

\begin{tabular}{|c|c|c|c|c|c|c|}
\hline & Local name & Scientific name & Family & Habit & Preference & Occurrence \\
\hline \multirow[t]{16}{*}{ Flower species } & Bagan bilash & Bougainvillea glabra Choisy in DC. & Nyctaginaceae & $\mathrm{S}$ & +++ & $\mathrm{C}$ \\
\hline & Bakul & Mimusops elengi Linn. & Sapotaceae & $\operatorname{Tr}$ & ++ & $\mathrm{FC}$ \\
\hline & Cactus & Buiningia brevicylindrica & Cactaceaea & $\mathrm{Ca}$ & +++ & $\mathrm{C}$ \\
\hline & Cosmos & Cosmos bipinnatus Linn. & Compositae & $\mathrm{H}$ & +++ & $\mathrm{C}$ \\
\hline & Ganda phol & Tagetes patula Linn. & Asteraceae & $\mathrm{H}$ & +++ & $\mathrm{C}$ \\
\hline & Golap & Rosa damascena Mill. & Rosaceae & Sh & +++ & $\mathrm{C}$ \\
\hline & Irish & Irish arvensis & Juglandaceae & $\mathrm{H}$ & ++ & $\mathrm{C}$ \\
\hline & Joba & Hibiscus rosa-sinensis Linn. & Malvaceae & Sh & + & $\mathrm{FC}$ \\
\hline & Jui & Jasminum officinalae & Oleaceae & Sh & ++ & $\mathrm{R}$ \\
\hline & Nayan tara & Vinca rosea & Apocynaceae & Sh & + & $\mathrm{R}$ \\
\hline & Patabahar & Codiaeum variegatum (Linn.) A.Juss. & Euphorbiaceae & $\mathrm{H}$ & +++ & $\mathrm{FC}$ \\
\hline & Rajoni gandha & Polianthese tuberose Linn. & Amaryllidaceae & $\mathrm{H}$ & +++ & $\mathrm{C}$ \\
\hline & Rongon & Ixora dussi & Rubuaceae & Sh & ++ & $\mathrm{FC}$ \\
\hline & Sheuli phol & Nyctanthus arbortristis Linn. & Oleaceae & Sh & ++ & $\mathrm{R}$ \\
\hline & Time phol & Gomphrena globosa Linn. & Amaranthaceae & $\mathrm{H}$ & ++ & $\mathrm{FC}$ \\
\hline & Togor & Tabernaemontana coronaria R.Br. & Apocynaceae & Sh & + & $\mathrm{R}$ \\
\hline
\end{tabular}

Habit: Tr-Tree, Sh-Shrub, H-Herb, Ca-Cactus; Preference: +++ High, ++ Medium, + Low; Occurrence: C-Common, FC-Fairly common, R-Rare.

a place for them to perform physical activity with privacy, safety and security. This is a favorite place, which appears to afford restorative experiences that aid emotion and self-regulation processes. For example, studies indicated that favorite place is visited to relax, calm down and clear minds (Korpela 1992; Korpela and Hartig 1996). Purpose of rooftop gardening was assessed using a semi-structured questionnaire. From the survey, it was found that each gardener was interested in rising of rooftop garden because they think that home gardens could help them to income and save money (29.8\%).

Trees have a positive effect in ameliorating environmental conditions (Zabala 1990). However, many respondents were also interested in environmental amelioration (54.9\%). Urban rooftop gardens and farms increase urban bio-diversity. They attract beneficial soil microorganisms, insects, birds, reptiles, and animals. Gardens play a role in species preservation for birds and butterflies by providing food, resting spaces, and protection along migratory flight paths (BSAT 1994; Towle 1996). The highest percentage was found in favor of mental satisfaction (95.3\%) and leisure time activity (87.8\%). Working with plants and in the outdoors benefits the mental health, mental outlook, and personal wellness of individuals (Matsuo and Relf 1995;
Table 4. Purpose of rooftop gardening in the study area

\begin{tabular}{lcc}
\hline Purpose of rooftop gardening & Respondents & Percentage \\
\hline Aesthetic value & 373 & 82.9 \\
Environmental amelioration & 247 & 54.9 \\
Financial gain & 134 & 29.8 \\
Leisure time activity & 395 & 87.8 \\
Luxury & 177 & 39.3 \\
Mental satisfaction & 429 & 95.3 \\
\hline
\end{tabular}

Brown et al. 2004). Gardeners report that sharing food with friends, families, neighbors, and/or needy members of their community in need are one of the important reasons that they grow produce. This also supported by various researchers in the world e.g. Hynes 1996; Patel 1996; Hanna 1999; Von Hassell 2002; Saldivar-Tanaka 2002. Result of investigation on purpose of roof gardening is shown in Table 4.

\section{Economic analysis of rooftop gardening in SCC}

\section{Initial investment (fixed cost)}

The fixed cost of rooftop gardening includes the cost of procuring planting base materials such as earthen pot, plastic containers, cemented drum and its preparation; cost for various planting tools (e.g. hoes, spades, sprinkles); plant- 


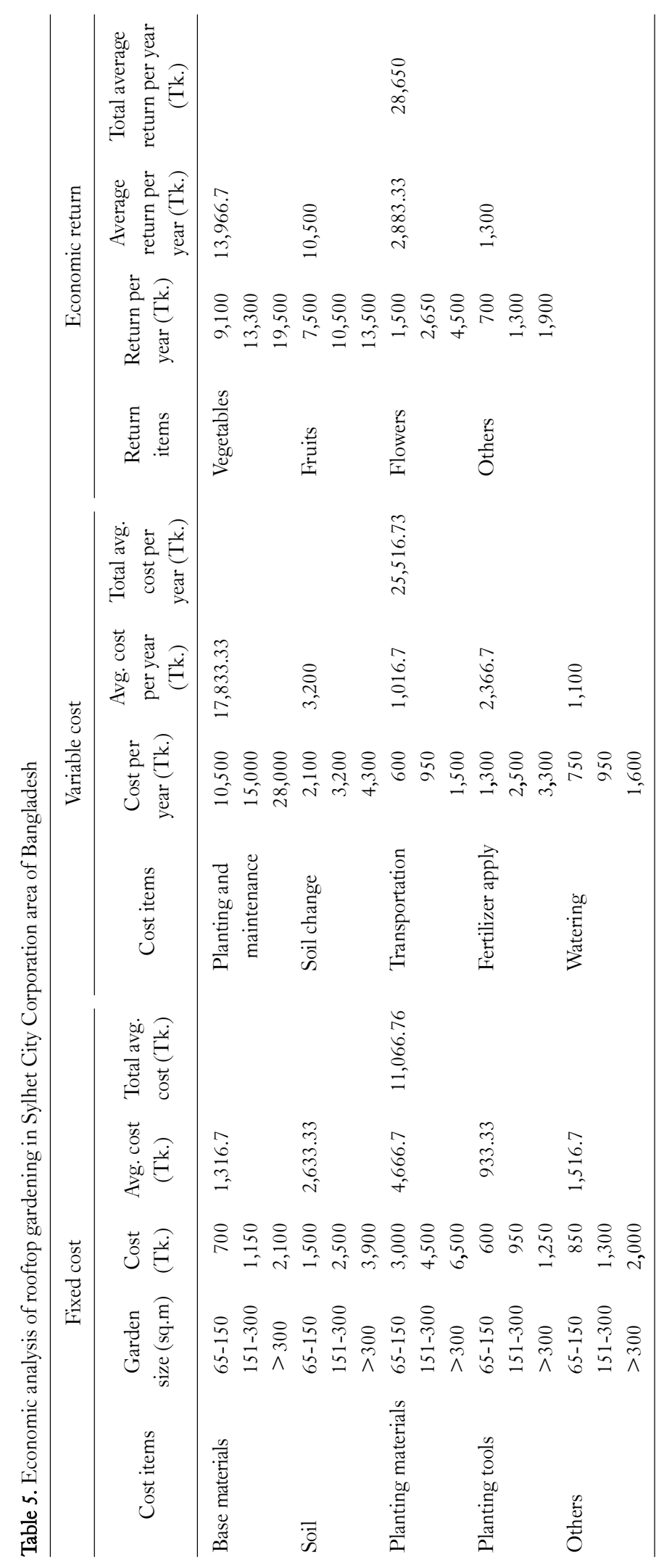


ing materials cost such as seeds, vegetative parts and seedlings, etc. Fixed cost varied according to roof size, species composition and permanent structure needed for maintenance. Following Table 5 shows the fixed cost for roof gardening:

\section{Variable cost}

Variable cost for rooftop gardening includes watering, fertilizers and insecticides uses, replanting, soil change, weeding, hoeing, etc. The amount of fertilizer and pesticide be applied depend on the nature of species and soil mixture. When gardeners spend the gardening time for another job and get some wages then this wage is the opportunity cost of roof gardening. Generally the urban dwellers work in garden either in morning or evening which is their leisure time. Moreover, they enjoy while gardening. Therefore, for roof gardening, the opportunity cost seems to be zero. The study identifies the following variable cost needed for roof gardening (Table 5).

\section{Economic return from the rooftop gardening}

Employment and income from small-scale non-farm activities, is of growing importance in the economy of developing countries (Hecht et al. 1988; Gunatilake et al. 1993; Arnold 1995). It was found from the survey that generally very few people consider rooftop gardening commercially to get profit. The return varies due to size and number of species. This analysis was done on the basis of average production and current price derived from current financial market. In the study area, rising rooftop gardening was found to be financially viable if the fixed cost is minimized after the first harvesting of the products such as vegetables, fruits, flowers and other products (Table 5). It was also reflected by the opinions of the respondents; all of them believed that rooftop gardening is a profitable option for securing their livelihoods as they collected their daily needs from the gardens and it is leisure time activity and sell the products after their consumption.

\section{Marketing of rooftop gardening products}

There was no organized marketing system of gardens products in the study area. Gardeners sell products sporadically in different local markets, directly or through intermediaries, with no uniform pricing for the products. The

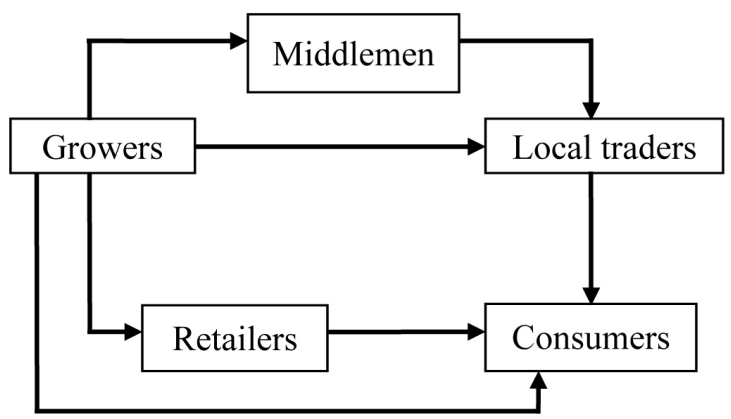

Fig. 1. Marketing flowchart of rooftop garden products in Sylhet City Corporation of Bangladesh.

first harvest was reported to be carried out 3 months after planting of vegetables and flowering plants. Fruits were harvest after 2-3 years of planting. In the study area, garden products were generally processed for individual's consumption only but middle and lower class gardeners sell their gardens products mostly to the local markets, traders and consumers such as neighbors for use; whereas higher class sell products directly to the local traders and retailers (Fig. 1). When they directly sell products to the retailers comparatively get more prices than the channel. Bakht (1984), argued that marketing is a leading constraint to the development of small-scale forest industries. Nair (1995), found that a substantial number of NWFPs supply to low-income markets, which impose limitations on possible income for producers of such products. From this study it was found that roof garden production, income and self use increases with the increasing size, investment and what purposes owner managed his garden (only aesthetic and/or subsistence income).

\section{Conclusion}

This study has shown that gardeners generally possess effective management techniques for rooftop gardening. It can easily be cultivated in roofs that remain under generally unused and these roofs are not suitable for cultivation of other cash crops. Rooftop greening also has aesthetic appeal, and offers the potential for health and mental therapy. Access to and even views of green roofs can increase property values, as well as increasing worker productivity and creativity. Rooftop gardening is slowly becoming more common in Bangladesh, particularly in the present study 
area, where rooftop food production may have a significant impact on food security and income. Previous study on rooftop gardening in Bangladesh was described only aesthetic and ecological values but our present study shows that rooftop gardening is not only an aesthetic culture to the gardeners moreover it has also a promising potential to improving the food security and meet nutritional deficiency to the gardeners. Present study also described the management and silvicultural techniques of rooftop gardening and also shows is a small scale business that can be accelerate additional family income and how can roof garden products marketed in the study area. Nevertheless, it may generate employment and economic facilities through its backward and forward linkages. Therefore, adequate training and motivation is required to encourage people to cultivate more plants and sustainable management and growth of rooftop gardening elsewhere in Bangladesh.

\section{References}

Arnold JEM. 1995. Socio-economic benefits and issues in nonwood forest products use. In: Report of the international expert consultation on Non-wood forest products. Non-Wood Forest Products 3, Food and Agriculture Organization (FAO), Rome, Italy, pp 89-123.

Bakht Z. 1984. Entrepreneurship in Bangladesh rural industries. Bangladesh Development Studies XII (1\&2): 25-58.

BBS (Bangladesh Bureau of Statistics). 2009. Statistical pocket book of Bangladesh-2008. planning division, ministry of planning, government of the people's republic of Bangladesh, Dhaka, Bangladesh.

Bellows AC, Hamm MW. 2003. International origins of community food security policies and practices in the U.S. Critical Public Health, Special Issue: Food Policy 13: 107-123.

Bienz DR. 1980. The why and how of home horticulture. W. H. Freeman publication, San Francisco, USA, pp 513.

Brown VM, Allen AC, Dwozan M, Mercer I, Warren K. 2004. Indoor gardening older adults: effects on socialization, activities of daily living, and loneliness. J Gerontol Nurs 30: 34-42.

BSAT (Biodiversity Science Assessment Team). 1994. Biodiversity in Canada: a scientific assessment. Ottawa, Environment Canada.

GRIS (Green Roof Industry Support). 2004. Eco-Roof/W.P. Hickman Systems. Available online at: www.ecoroofsystems.com/ news_files/c_green.html. Accessed 23 Jul 2010.

Gunatilake HM, Senaratine DMAH, Abeygunawardena P. 1993. Role of Non-Timber Forest Products in the Economy of Peripheral Communities of Knuckles National Wilderness Area of Sri Lanka: A Farming Systems Approach. Economic Botany 47: 275-281.

Hamm MW, Bellows AC. 2003. Community food security and nutrition educators. J Nut Edu Behav 35: 37-43.

Hanna A. 1999. Growing Food and Community Social Capital, M. S. Dissertation. Penn State University (Sociology and African-American Studies). Available online at: www.geog.psu.edu/phila/hannaoh.html. Accessed 18 Aug 2010.

Hecht SB, Anderson A, May P. 1988. The subsidy from nature: shifting cultivation, successional palm forests and rural development. Human Organization 47: 25-35.

Hynes HP. 1996. A Patch of Eden: America's Inner-City Gardeners. Chelsea White River Jct, VT: Green Publishing Company, United Kingdom.

Koc M, MacRae R, Mougeot LJA, Welsh J. 1999. For HungerProof Cities: Sustainable Urban Food Systems. Toronto: International Development Research Centre (IDRC) and the Centre for Studies in Food Security, Ryerson Polytechnic University, Canada.

Korpela K, Hartig T. 1996. Restorative Qualities of Favorite Places. J Environ Psycho 16: 221-233.

Korpela K. 1992. Adolescents' favourity places and environmental self-regulation. J Environ Psycho 12: 249- 258.

Mann P. 2001. Why Homeland Security Must Include Food Security. World Hunger Year (WHY) Commentary. Available online at: www.worldhungeryear.org/why_speaks/ws_load.asp?file $=568$ style $=$ ws_table. Accessed 21 Sep 2010 .

Matsuo E, Relf PD. 1995. Horticulture in Human Life, Culture, and Environment. A National Symposium (proceedings), Acta Horticulturae, IHC Proceedings, Number 391.

Nair CTS. 1995. Income and employment from non-wood forest products. In: Proceedings of Regional Expert Consultation: Beyond Timber: Social, Economic and Cultural Dimensions of Non-wood Forest Products in Asia and the Pacific (Durst PB, Bishop A, eds). FAO/RAP, Rome, pp 87-95.

Nowak M. 2004. Urban agriculture on the rooftop, senior honors dissertation. Cornell University, New York, USA, pp 75.

Pant MM. 1994. Forest Resources Management. Institute of Forestry and Environmental Sciences, University of Chittagong, Chittagong, Bangladesh, FAO/UNDP/BGD, pp 79-83.

Patel IC. 1996. Rutgers urban gardening: A case study in urban agriculture. J Agr Food Inform 3: 35-46.

Peck S. 2003. Towards and Integrated Green Roof Infrastructure Evaluation for Toronto. The Green Roof Infrastructure Monitor $5: 4-5$.

Rahman MH. 2010. Urbanization and Hill Cutting: Study on Environmental Change in Sylhet, Bangladesh. B. Sc. (Hons.) Dissertation. Department of Forestry and Environmental Science, School of Agriculture and Mineral Sciences, Shahjalal University of Science and Technology, Sylhet, Bangladesh, pp 107.

Rahman MH, Fardusi MJ, Roy B, Kamal, MM, Uddin MJ, Khan MASA. 2012. Production, Economics, Employment 
Generation and Marketing Pattern of Rattan-Based Cottage Enterprises: A Case Study from an Urban Area of NorthEastern Bangladesh. Small-scale Forestry 11: 207-221.

Rashid R, Ahmed MHB. 2009. The passive cooling effect of green roof in high-rise residential building in malaysia. Sustainable Architecture and Urban Development, CSAAR, 3-6 November. Rashid R, Ahmed MHB. Khan MS. 2010. Green roof and its Impact on Urban Environmental sustainability: The Case in Bangladesh. World J Manag 2: 59-69.

Sajjaduzzaman M, Koike M, Muhammed N. 2005. An analytical study on cultural and financial aspects of roof gardening in dhaka metropolitan city of Bangladesh. Int J Agri Biol 7: 184-187.

Saldivar-Tanaka L. 2002. Culturing neighborhood open space, civic agriculture, and community development: the case of latino community gardens in New York City, M. S. Dissertation,
Cornell University, pp 87.

SCC (Sylhet City Corporation) 2010. Official website of Sylhet City Corporation. Available online at: www.sylhetcitycorporation. org. Accessed 7 Aug 2010.

Sedjo RA. 1989. Foresters to Offset the Greenhouse Effect. Journal of Forestry 87: 12-13.

Towle K. 1996. The role of ecological restoration in biodiversity conservation: basic issues and guidelines. The Evergreen Foundation, Toronto.

Von-Hassell M. 2002. The struggle for eden: community gardens in New York City. Bergin and Garvey, Westport, CN.

Zabala NQ. 1990. Arboriculture, development of professional education in the forestry sector of Bangladesh. Institute of Forestry and Environmental Sciences, University of Chittagong, Chittagong, Bangladesh, pp 72. 